\title{
ANALISIS LAPORAN KEUANGAN BERDASARKAN STANDAR AKUNTANSI KEUANGAN ENTITAS TANPA AKUNTABILITAS PUBLIK (SAK ETAP) PADA ORYZA MART JEMBER PERIODE 2017
}

\author{
M. Ainul Fadlol ${ }^{1}$, Titin Kartini ${ }^{1}$, Sri Kantun ${ }^{1}$ \\ ${ }^{1}$ Program Studi Pendidikan Ekonomi, Fakultas Keguruan dan Ilmu Pendidikan, Universitas Jember \\ e-mail: fadol.silver07@gmail.com
}

\begin{abstract}
Abstrak
Penelitian ini bertujuan untuk menganalisis kesesuaian laporan keuangan Oryza Mart Jember periode 2017 dengan SAK ETAP 2016. Penentuan lokasi penelitian menggunakan metode purposive area. Metode pengumpulan data menggunakan dokumen dan wawancara. Analisis data dalam penelitian ini menggunakan analisis deskriptif komparatif. Hasil analisis menunjukkan bahwa penyusunan laporan keuangan yang dilakukan oleh Oryza Mart Jember pada periode 2017 masih belum memenuhi kelengkapan menurut SAK ETAP. Oryza Mart belum menyusun laporan arus kas dan catatan atas laporan keuangan dan hanya menyusun 3 laporan keuangan yaitu Neraca, Laporan Laba Rugi, dan Laporan Perubahan Modal. Ketidak sesuaian juga terdapat di dalam Neraca, yaitu belum ada klasifikasi terpisah antara peralatan toko dan peralatan kantor, gedung dan tanah. Selain itu, Oryza Mart belum memisahkan kewajiban jangka pendek dan kewajiban jangka panjang.
\end{abstract}

Kata kunci : Laporan keuangan, SAK ETAP, Oryza Mart.

\section{PENDAHULUAN}

Penyusunan laporan keuangan menjadi hal penting yang harus disusun oleh suatu unit. Laporan keuangan yang disusun berfungsi sebagai alat informasi yang menghubungkan perusahaan dengan pihak-pihak yang memiliki kepentingan dengan laporan keuangan perusahaan (Hery, 2016:3). Bagi pihak internal laporan keuangan ini dapat berfungsi sebagai media untuk mengukur kinerja keuangan perusahaan dan memantau perkembangan perusahaan. Sedangkan bagi pihak eksternal yang memiliki kepentingan dengan laporan keuangan perusahaan dapat dijadikan sebagai informasi bahan pertimbangan dalam pemberian modal. Perusahaan berskala besar maupun kecil seperti UMKM tentunya harus menyusun laporan keuangan yang sesuai standar. Standar penyusunan laporan keuangan ditetapkan oleh Ikatan Akuntan Indonesia.

Ikatan Akuntan Indonesia (IAI) telah menerbitkan Standar Penyusunan Laporan Keuangan Entitas Tanpa Akuntabilitas Publik (SAK ETAP) pada 17 Juli 2009 dan berlaku efektif per 1 Januari 2011. SAK ETAP diperuntukkan bagi perusahaan berskala kecil seperti UMKM untuk memudahkan pelaku usaha kecil dalam menyusun laporan keuangannya sendiri. Laporan keuangan menurut SAK ETAP meliputi; neraca, laporan laba rugi, laporan perubahan modal, laporan arus kas dan catatan atas laporan keuangan.

Salah satu UMKM yang berada di Kabupaten Jember yaitu Oryza Mart yang merupakan usaha dagang model mini market. Oryza Mart sudah berdiri sejak \pm 7 tahun lalu, sejak awal berdiri UMKM ini sudah melakukan penyusunan laporan keuangan yang rutin. Laporan keuangan yang di susun oleh Oryza Mart meliputi; neraca, laporan laba rugi dan laporan perubahan modal. Menurut pemilik laporan tersebut sudah dapat memberikan informasi yang cukup bagi peruhaan. Hal ini sesuai dengan pendapat Munawir (2014:5) laporan keuangan terdiri dari neraca, laporan laba rugi dan laporan perubahan modal, ketiga komponen laporan keuangan tersebut sudah dapat mencerminkan kondisi keuangan suatu unit usaha.

Neraca merupakan laporan keuangan yang menunjukkan posisi keuangan perusahaan pada tanggal tertentu (Kasmir, 2016:28). Posisi keuangan yang dimaksud yaitu jumlah dan jenis aktiva (harta) dan pasiva (kewajiban dan modal). Sedangkan laporan laba rugi adalah laporan yang disusun untuk menggambarkan hasil perusahaan selama periode tertentu. Laporan laba rugi berkaitan dengan pendapatan dan biaya-biaya yang dikeluarkan perusahaan selama satu periode. Laporan perubahan modal merupakan laporan yang menunjukkan sebab-sebab perubahan modal setelah ditambah laba atau dikurangi rugi. Wahyudiono (2014:39) menjelaskan 
bahwa laporan perubahan modal merupakan laporan yang menjelaskan perubahan modal pemilik selama jangka waktu tertentu.

Selama \pm 7 tahun berdiri Oryza Mart sudah menyusun ketiga komponen laporan keuangan tersebut yaitu; neraca, laporan laba rugi serta laporan perubahan modal. Namun berdasarkan informasi yang awal yang diterima oleh peneliti Oryza Mart masih belum mengetahui apakah laporan keuanga yang disusun sudah sesuai dengan standar yang berlaku atau belum. Laporan keuangan yang disusun oleh Oryza Mart tentunya harus menyesuaikan dengan standar yang berlaku. Untuk perusahaan kecil menengah seperti Oryza Mart sudah terdapat SAK ETAP yang mempermudah penyusunan laporan keuangan. Oleh karena itu, peneliti tertarik untuk melakukan penelitian dengan judul "Analisis Laporan Keuangan Berdasarkan Standar Akuntansi Keuangan Entitas Tanpa Akuntabilitas Publik (Sak Etap) Pada Oryza Mart Jember Periode 2017”.

\section{METODE}

Penelitian ini merupakan penelitian evaluatif dengan analisis data deskriptif komparatif. Penentuan lokasi penelitian menggunakan metode purposive area yaitu di Oryza Mart Jember. Jenis data yang digunakan yaitu data primer dan data sekunder. Data primer yaitu laporan keuangan Oryza Mart yang diperoleh dari dokumen. Sedangkan data sekunder yaitu profil usaha dan denah lokasi yang diperoleh dari hasil wawancara dan obeservasi. Metode pengumpulan data menggunakan dokumen dan wawancara. Analisis data dalam penelitian ini menggunakan analisis deskriptif komparatif yaitu dengan membandingkan teori-teori dengan praktik yang terjadi di lapangan, dan kemudian mengambil kesimpulan dari hasil perbandingan tersebut. Adapun langkah-langkah analisis data sebagai berikut:

1. Mendeskripsikan data sehingga memberikan keterangan yang lengkap bagi masalah yang dihadapi. Pada tahap ini peneliti memaparkan penyusunan laporan keuangan Oryza Mart periode 2017 yang terdiri dari Neraca, Laporan Laba Rugi, dan Laporan Perubahan modal.

2. Membandingkan penyusunan laporan keuangan dengan standar yang berlaku. Peneliti membuat tabel perbandingan penyusunan laporan keuangan sesuai SAK ETAP dengan praktik yang terjadi di dalam penyusunan laporan keuangan Oryza Mart periode 2017.

3. Mengevaluasi hasil perbandingan dengan mengambil kesimpulan tentang penerapan SAK ETAP dalam penyusunan laporan keuangan di Oryza Mart periode 2017.

\section{HASIL DAN PEMBAHASAN}

\section{Hasil Penelitian}

Dari hasil analisis terhadap dokumen laporan keuangan Oryza Mart diperoleh data mengenai laporan keuangan yang disusun pada periode 2017. Berikut ini merupakan analisis mengenai penyajian laporan keuangan yang disusun oleh Oryza Mart yang ditinjau dari kepatuhannya terhadap SAK ETAP. Dalam SAK ETAP terdapat 5 komponen laporan keuangan yang harus disusun oleh entitas sehingga laporan keuangan dapat dikatakan lengkap. Berikut ini merupakan tabel daftar laporan keuangan yang harus disusun oleh entitas:

Tabel 1. Kelengkapan Laporan Keuangan Oryza Mart

\begin{tabular}{|l|l|c|}
\hline No & Elemen Laporan Keuangan & Ada/Tidak \\
\hline 1 & Neraca & $\sqrt{ }$ \\
2 & Laporan Laba Rugi & $\sqrt{ }$ \\
3 & Laporan Perubahan Modal yang juga menunjukkan: & $\sqrt{ }$ \\
& a. Seluruh perubahan dalam modal, atau \\
& b. Perubahan ekuitas selain perubahan dari transaksi \\
& dengan pemilik dalam kapasitasnya sebagai & \\
4 & pemilik. & $\times$ \\
5 & Laporan Arus Kas & $\times$ \\
\hline
\end{tabular}


Sumber: Hasil Olah Data Sekunder, 2018

Tabel di atas menunjukkan bahwa Oryza Mart menyusun 3 dari 5 komponen laporan keuangan yang disyaratkan dalam SAK ETAP. Oryza Mart hanya menyajikan neraca, laporan laba rugi dan laporan perubahan modal. Jadi dapat dilihat bahwa laporan keuangan yang disajikan oleh Oryza Mart belum dapat dinyatakan lengkap menurut SAK ETAP. Berdasarkan informasi yang diterima dari pemilik Oryza Mart, pencatatan laporan arus kas dan catatan atas laporan keuangan tidak disusun karena ketiga komponen laporan keuangan yang disusun sudah dapat memberikan informasi keuangan yang memadai. Penyusunan laporan laba rugi sudah dirasa cukup untuk memberikan informasi mengenai arus kas masuk dan keluar. Sedangkan untuk catatan atas laporan keuangan tidak disusun karena hanya memberikan informasi mengenai standar penyusunan laporan keuangan yang digunakan.

Penyusunan neraca, laporan laba rugi dan perubahan modal sudah dirasa cukup untuk memberikan informasi mengenai posisi keuangan UMKM. Hal tersebut sesuai dengan pendapat Munawir (2014:5) yang menjelaskan bahwa laporan keuangan terdiri dari neraca, perhitungan laba rugi dan laporan perubahan modal. Ketiga komponen laporan keuangan tersebut sudah dapat mencerminkan kondisi keuangan suatu unit usaha. Berikut tabel Perbandingan Neraca SAK ETAP dengan Oryza Mart:

Tabel 1.2 Perbandingan Neraca SAK ETAP dengan Oryza Mart

\begin{tabular}{|c|c|c|c|c|}
\hline No & $\begin{array}{c}\text { Item yang } \\
\text { Dibandingkan }\end{array}$ & SAK ETAP & Oryza Mart & Keterangan \\
\hline \multirow[t]{2}{*}{1} & \multirow[t]{2}{*}{ Aset } & \multirow[t]{2}{*}{$\begin{array}{l}\text { Neraca minimal menyajikan } \\
\text { pos - pos berikut: } \\
\text { a. Kas dan setara kas } \\
\text { b. Piutang usaha dan piutang } \\
\text { lainnya } \\
\text { c. Persediaan } \\
\text { d. Properti investasi (tanah } \\
\text { dan bangunan) } \\
\text { e. Aset tetap }\end{array}$} & $\begin{array}{l}\text { Pos - pos aset yang disajikan oleh } \\
\text { Oryza Mart: } \\
\text { Aset Lancar: } \\
\text { - Kas } \\
\text { - Kas di Bank } \\
\text { - Piutang dagang } \\
\text { - Persediaan barang } \\
\text { - dagangan } \\
\text { - Perlengkapan toko } \\
\end{array}$ & Sesuai \\
\hline & & & $\begin{array}{l}\text { Aset Lancar: } \\
\text { • Peralatan } \\
\text { • Akumulasi penyusutan } \\
\text { peralatan } \\
\text { • Gedung } \\
\text { • Akumulasi penyusutan } \\
\text { gedung } \\
\text { - Kendaraan roda } 3 \\
\text { - Akumulasi penyusutan } \\
\text { kendaraan roda } 3 \\
\text { - Komputer } \\
\text { - Akumulasi penyusutan } \\
\text { komputer }\end{array}$ & Kurang Sesuai \\
\hline 2 & Kewajiban & $\begin{array}{l}\text { Kewajiban minimal menyajikan } \\
\text { pos-pos meliputi: } \\
\text { h. Hutang usaha dan hutang } \\
\text { lainnya } \\
\text { - Hutang jangka pendek } \\
\text { - Hutang jangka panjang }\end{array}$ & $\begin{array}{l}\text { Pos }- \text { pos kewajiban yang } \\
\text { disajikan oleh Oryza Mart: } \\
\text { - Hutang dagang } \\
\text { - Hutang bank }\end{array}$ & Kurang Sesuai \\
\hline & Ekuitas & Entitas menyajikan pos, judul, & Pos - pos modal yang disajikan & \\
\hline
\end{tabular}




\begin{tabular}{|l|l|l|l|}
\hline & $\begin{array}{l}\text { dan sub jumlah lainnya } \\
\text { i. Modal }\end{array}$ & oleh Oryza Mart: & Sesuai \\
$\bullet \quad$ Modal pemilik & $\bullet \quad$ Prive & \\
\hline
\end{tabular}

Sumber: Hasil Olah Data Sekunder, 2018

Berdasarkan tabel di atas penyusunan neraca Oryza Mart sudah sesuai dengan kaidah SAK ETAP. Oryza Mart menyajikan informasi mencakup pos-pos aktiva lancar, aktiva tetap, kewajiban dan ekuitas telah sesuai karena akun-akun atau pos-pos dalam neraca telah disajikan secara terpisah berdasarkan sifatnya masing-masing pos.

Berikut tabel Perbandingan laba rugi SAK ETAP dengan Oryza Mart:

Tabel 1.3 Perbandingan Laporan Laba Rugi SAK ETAP dengan Oryza Mart

\begin{tabular}{|c|c|c|c|c|}
\hline No & $\begin{array}{c}\text { Item yang } \\
\text { Dibandingkan }\end{array}$ & SAK ETAP & Oryza Mart & Keterangan \\
\hline \multirow[t]{2}{*}{1} & $\begin{array}{l}\text { Informasi } \\
\text { yang disajikan }\end{array}$ & $\begin{array}{l}\text { Laporan laba rugi minimal } \\
\text { menyajikan pos-pos berikut: } \\
\text { a. Penghasilan } \\
\text { - Penghasilan usaha } \\
\text { - Peghasilan luar usaha } \\
\text { b. Beban } \\
\text { - Beban usaha } \\
\text { - Beban luar usaha } \\
\text { c. Beban pajak } \\
\text { d. Laba atau rugi neto }\end{array}$ & $\begin{array}{l}\text { Pos - pos dalam laporan laba } \\
\text { rugi Oryza Mart: } \\
\text { a. Penjualan atau } \\
\text { pendapatan usaha } \\
\text { - Pendapatan usaha } \\
\text { - Pedapatan luar usaha } \\
\text { b. Harga pokok penjualan } \\
\text { c. Beban usaha } \\
\text { - Beban operasional } \\
\text { - Beban umum dan } \\
\text { administrasi } \\
\text { d. Laba usaha }\end{array}$ & \multirow{2}{*}{$\begin{array}{l}\text { Sesuai } \\
\text { Sesuai }\end{array}$} \\
\hline & & $\begin{array}{l}\text { Entitas harus menyajikan pos, } \\
\text { judul, dan sub jumlah lainnya } \\
\text { pada laporan laba rugi jika } \\
\text { berpengaruh } \\
\text { pengeluaran dan pemasukan } \\
\text { entitas. }\end{array}$ & $\begin{array}{ll}\text { e. } & \text { Pendapatan luar usaha } \\
\text { f. } & \text { Beban luar usaha } \\
\text { g. } & \text { Beban pajak } \\
& \text { penghasilan }\end{array}$ & \\
\hline
\end{tabular}

Sumber: Hasil Olah Data Sekunder, 2018

Laporan laba rugi Oryza Mart melaporkan pendapatan dan beban selama satu periode. Dalam laporan laba rugi Oryza Mart sudah menyajikan pendapatan, beban usaha, laba serta pajak penghasilan. Dalam laporan laba rugi Oryza Mart sudah mengklasifikasikan beban berdasarkan sifatnya, seperti biaya operasionanl dan biaya umum dan administrasi. Selain itu Oryza Mart sudah mengungkapkan pajak penghasilan sebagai beban yang diakui secara terpisah dari beban usaha.

Berikut tabel Perbandingan laba rugi SAK ETAP dengan Oryza Mart:

Tabel 1.4 Perbandingan Laporan Perubahan Modal SAK ETAP dengan Oryza Mart 


\begin{tabular}{|c|c|c|c|c|}
\hline No & $\begin{array}{c}\text { Item yang } \\
\text { Dibandingkan }\end{array}$ & SAK ETAP & Oryza Mart & Keterangan \\
\hline \multirow[t]{2}{*}{1} & $\begin{array}{l}\text { Informasi yang } \\
\text { disajikan }\end{array}$ & $\begin{array}{l}\text { Entitas menyajikan laporan } \\
\text { perubahan modal yang } \\
\text { menunjukkan: } \\
\text { a. Laba atau rugi untuk periode } \\
\text { b. Pendapatan dan/atau beban } \\
\text { yang disajikan langsung dalam } \\
\text { ekuitas }\end{array}$ & \multirow[t]{2}{*}{$\begin{array}{l}\text { Laporan perubahan modal yang } \\
\text { disajikan Oryza Mart: } \\
\text { a. Modal awal } 1 \text { Januari } \\
\\
\text { b. Laba usaha } \\
\text { c. Pengambilan pribadi } \\
\text { d. Modal akhir } 31 \\
\\
\text { Desember } 2017\end{array}$} & \multirow[t]{2}{*}{ Sesuai } \\
\hline & & $\begin{array}{l}\text { Laporan perubahan modal } \\
\text { menyajikan laba atau rugi } \\
\text { entitas dan perubahan saldo } \\
\text { laba suatu periode pelaporan. }\end{array}$ & & \\
\hline
\end{tabular}

Sumber: Hasil Olah Data Sekunder, 2018

Laporan perubahan modal Oryza Mart sudah mencakup semua komponen yang diatur dalam SAK ETAP. Dimana dalam laporan perubahan modal Oryza Mart sudah memasukkan modal awal, laba, prive dan modal akhir perusahaan. Hal ini sesuai dengan SAK ETAP yang menyatakan bahwa entitas harus menyajikan laba rugi periode, pos pendapatan dan beban yang diakui dalam modal untuk periode tersebut SAK ETAP (2016:21) paragraf 6.2.

\section{Pembahasan}

Penyajian laporan keuangan yang dilakukan oleh Oryza Mart pada periode 2017 masih belum memenuhi kelengkapan menurut SAK ETAP. Oryza Mart masih belum menyajikan laporan arus kas dan catatan atas laporan keuangan. Dalam SAK ETAP mengatur bahwa entitas harus menyajikan 5 komponen laporan keuangan yaitu; neraca, laporan laba rugi, laporan perubahan modal, laporan arus kas dan catatan atas laporan keuangan. Sementara laporan keuangan yang disusun oleh Oryza Mart hanya mencakup 3 komponen yaitu; neraca, laporan laba rugi serta laporan perubahan modal. Bagi unit usaha kecil menengah seperti Oryza Mart ketiga komponen tersebut sudah dapat memberikan informari keuangan yang cukup.

Hal ini sesuai dengan pendapat Munawir (2014:5) yang menjelaskan bahwa laporan keuangan terdiri dari neraca, perhitungan laba rugi dan laporan perubahan modal. Ketiga komponen laporan keuangan tersebut sudah dapat mencerminkan kondisi keuangan suatu unit usaha. Oryza Mart tidak menyusun 2 dari lima komponen yang telah ditetapkan oleh SAK ETAP karena pemilik menganggap bahwa ketiga komponen laporan keuangan yang disusun sudah cukup untuk memberikan informasi mengenai posisi keuangan Oryza Mart. Pemilik merasa untuk usaha berskala kecil menengah seperti Oryza Mart cukup menyajikan ketiga komponen tersebut. Hal ini seperti yang disampaikan oleh pemilik Oryza Mart.

"Bagi unit usaha kecil seperti Oryza Mart penyusunan neraca, laporan laba rugi dan laporan perubahan modal sudah memberikan informasi yang cukup mengenai kondisi keuangan toko. Dengan menyusun laporan laba rugi sudah dapat melihat semua pemasukan dan biaya-biaya yang dikeluarkan selama kegiatan operasional berlangsung. Jadi saya rasa saat ini Oryza Mart belum memerlukan untuk membuat laporan arus kas serta catatan atas laporan keuangan. Laporan arus kan sudah terwakili oleh laporan laba rugi dan untuk catatan atas laporan keuangan hanya berisikan informasi mengenai kebijakan pencatatan akuntansi. Jadi menurut saya laporan keuangan yang saya susun sekarang sudah dapat memberikan informasi keuangan yang cukup." (Syamsuri, 46). 
Penyajian laporan keuangan yang disusun oleh Oryza Mart masih ada beberapa yang belum sesuai dengan kaidah penyusunan laporan keuangan dalam SAK ETAP. Hal ini ditemukan dalam kesalahan penyusunan neraca terkait kesalahan dalam pengakuan dan pengklasifikasian pada akun-akun yang termuat dalam neraca Oryza Mart. Dalam pengklasifikasian harta Oryza Mart sudah memisahkan antara harta lancar dan harta tetap, namun terdapat ketidak sesuaian dalam pengkalasifikasian harta tetap. Dimana Oryza Mart belum mengklasifikasikan secara terpisah peralatan kantor dan peralatan toko serta gedung dan tanah.

Pada harta tetap Oryza Mart menggabungkan antara peralatan toko dan peralatan kantor menjadi satu. Hal ini tentu menyimpang dari pengertian peralatan toko dan peralatan kantor menurut akuntansi. Alasan pemilik tidak membedakan peralatan kantor dan peralatan toko karena gedung toko dan kantor Oryza Mart menjadi satu sehingga untuk memudahkan pencatatan peralatan tidak dibedakan. Hal ini seperti yang disampaikan pemilik Oryza Mart.

"Saya memang tidak melakukan pemisahan antara peralatan toko dan peralatan kantor dalam neraca. Karena gedung toko dan kantor satu bangunan dan peralatan yang ada tidak terlalu banyak, jadi semua peralatan yang ada dijadikan satu. Hal ini juga bertujuan untuk memudahkan ketika toko melakukan penyusutan terhadap peralatan." (Syamsuri, 46).

Oryza Mart tidak melakukan pengklasifikasian terhadap peralatan karena untuk memudahkan dalam melakukan penyusutan di akhir periode. Selain itu juga perlatan yang ada belum terlalu banyak sehingga Oryza Mart belum memerlukan untuk melakukan pengklasifikasian terhadap akun peralatan. Hal tersebut juga karena gedung yang digunakan untuk operasional masih menjadi satu bangunan antara toko dan kantor.

Ketidak sesuaian yang kedua terkait dengan pengklasifikasian gedung dan tanah. Dalam pelaporan neraca yang disusun oleh pemilik Oryza Mart belum terlihat pelaporan untuk tanah. Sehingga penyusutan yang dibebankan kepada gedung menjadi terlalu tinggi. Hal ini tentu bertentangan dengan kaidah dalam SAK ETAP yang mengharuskan bahwa tanah dan gedung merupakan aset yang dapat dipisahkan dan harus dicatat secara terpisah, meskipun tanah dan bangunan tersebut diperoleh secara bersamaan (SAK ETAP, 2016:49). Hal ini seperti yang disampaikan oleh pemilik Oryza Mart.

"Dalam neraca saya memang tidak memunculkan akun tanah, karena tanah dan bangunan saya jadikan satu sebagai aset tetap gedung. Gedung dan tanah Oryza Mart diperoleh secara bersamaan maka dari itu saya tidak melakukan pemisahan terhadap aset tanah dan gedung. Saya mencatat aset tanah sesuai dengan harga perolehan besama gedung di dalam neraca." (Syamsuri,46).

Ketidak sesuaian yang ketiga yaitu terkait dengan kewajiban dalam neraca. Berdasarkan hasil analisis yang telah dilakukan peneliti, Oryza Mart sudah mengklasifikasikan kewajiban berdarkan jangka waktunya. Oryza Mart mempunyai dua kewajiban yaitu hutang dagang dan hutang bank, hutang dagang dikategorikan sebagai kewajiban jangka pendek yang penyelesaiannya kurang dari 1 tahun atau 1 periode. Sedangkan kewajiban pada bank dikategorikan sebagai kewajiban jangka panjang yang penyelesaiannya lebih dari 1 peride.

Namun penyajian kewajiban dalam neraca Oryza Mart tidak mengklasifikasikan kewajiban jangka pendek dan kewajiban jangka panjang sebagai suatu klasifikasi yang berbeda. Oryza Mart menyajikan kewajiban jangka pendek dan jangka panjang sebagai suatu klasifikasi yang sama dalam neraca. Hal ini tentu tidak sesuai dengan kaidah SAK ETAP (2016:15) paragraf 4.5 yang menyatakan bahwa entitas harus menyajikan kewajiban jangka pendek dan jangka panjang sebagai suatu klasifikasi yang terpisah dalam neraca sesuai paragraph 4.6-4.9. Alasan pemilik tidak mengklasifikasikan hutang jangka pendek dan jangka panjang secara terpisah karena Oryza Mart hanya memiliki dua kewajiban yaitu hutang dagang dan hutang bank. hal ini seperti yang dikatakan pemilik Oryza Mart.

"Dalam neraca saya memang tidak mengklasifikasikan secara terpisah kewajiban jangka pendek dan kewajiban jangka panjang. Hal tersebut karena kewajiban yang dimiliki toko hanya ada 2 macam yaitu hutang dagang dan hutang bank. Sehingga tidak perlu untuk dibedakan karena hanya ada 2 akun tersebut. Sedangkan dalam pengakuan kami tetap ada kewajiban jangka pendek dan kewajiban jangka panjang. Hutang dagang saya 
kategorikan sebagai kewajiban jangka pendek karena penyelesaiannya dilakukan kurang dari satu periode. Sedangkan hutang bank saya kategorikan sebagai hutang jangka panjang karena penyelesaiannya lebih dari satu periode" (Syamsuri, 46).

Oryza Mart tidak melakukan pengklasifikasian secara terpisah kewajiban jangka pendek dan jangka panjang dalam nercara. Hal itu karena kewajiban yang diakui oleh Oryza Mart hanya ada 2 akun yaitu hutang dagang dan hutang bank. Hal itu dilakukan untuk mempermudah pencatatan dalam neraca. Hal ini juga dibenarkan dalam SAK ETAP paragraf 4.5 yang menyatakan entitas harus menyajikan aset lancar dan aset tetap, kewajiban jangka panjang dan jangka pendek secara terpisah dalam neraca, kecuali jika penyajian berdasarkan likuiditasnya yang lebih andal dan relevan SAK ETAP (2016:15).

\section{PENUTUP}

Berdasarkan hasil penelitian dan pembahasan, dapat disimpulkan secara garis besar bahwa penyusnan laporan keuangan Oryza Mart periode 2017 sudah sesuai dengan SAK ETAP. Meskipun masih terdapat beberapa kendala dalam pengakuan akun dan pengklasifikasian akun, namun secara garis besar penyusunan neraca, laporan laba rugi dan perubahan modal yang disusun sudah sesuai dengan kaidah SAK ETAP.

Hal ini dibuktikan dalam penyusunan neraca Oryza Mart sudah mengklasifikasikan akun aktiva lancar dan aktiva tetap sebagai suatu klasifikasi yang berbeda, Oryza Mart juga sudah memasukkan komponen kewajiban dan modal dalam neraca. Laporan laba rugi yang disusun oleh Oryza Mart juga sudah memenuhi kaidah SAK ETAP dimana dalam laporan laba rugi sudah mengklasifikasikan beban berdasarkan sifatnya dan memasukan beban pajak sebagai klasifikasi yang terpisah dari beban usaha. Laporan perubahan modal yang disusun juga sudah memenuhi standar, dimana terdapat modal awal, laba, prive dan modal akhir.

Berdasarkan hasil penelitian ini, maka peneliti dapat memberikan saran yaitu Oryza Mart bisa terus konsisten melakukan pencatatan laporan keuangan yang sesuai dengan standar yang berlaku bagi UMKM. Serta dapat mematuhi segala peraturan yang telah ditetapkan oleh standar tersebut.

\section{DAFTAR PUSTAKA}

Hery. 2016. Analisis Laporan Keuangan. Jakarta: PT Grasindo.

Ikatan Akuntan Indonesia. 2016. Standar Akuntansi Keuangan Entitas Tanpa Akuntabilitas Publik. Jakarta: Ikatan Akuntansi Indonesia.

Kasmir. 2016. Analisis Laporan Keuangan. Jakarta: Rajawali Pers.

Munawir, S. 2014. Analisa Laporan Keuangan. Yogyakarta: Liberty.

Wahyudiono, B. 2014. Mudah Membaca Laporan Keuangan. Jakarta: Raih Asa Sukses. 